Антонина Мороз

\title{
ИЗБЫ-ЧИТАЛЬНИ ВОСТОЧНОГО ЗАБАЙКАЛЬЯ В 1920-е гГ.
}

Статья посвящена изучению становления и деятельности советских политико-просветительных учреждений, создаваемых для обслуживания взрослого крестьянства- изб-читален в Восточном Забайкалье. Автором привлечены ранее не введённые в научный оборот документы из фондов Государственного архива Забайкальского края и Государственного архива Хабаровского края, а также материалы периодической печати 1920-х гг. Уточнено, что создание сети изб-читален в Восточном Забайкалье началось позднее, чем в центральных регионах страны. В годы Гражданской войны местная сеть образовательных и просветительных учреждений была разрушена и её восстановление стало возможным только в условиях Дальневосточной республики. В 1920-1922 гг. в регионе создавались и действовали учреждения разных типов- библиотеки, народные дома, клубы, культурно-просветительные кружки. Однако изученные исторические источники не содержат сведений о избах-читальнях. Основной причиной была децентрализация управления народным образованием и просвещением в республике, а также высокая степень участия населения региона в создании просветительных учреждений. Это обусловило самостоятельность и автономность забайкальских просветительных учреждений для взрослых - они вели свою деятельность без каких-либо планов, программ, инструкций, не были ограничены в определении содержания своей работы. После установления советской власти в Восточном Забайкалье создаются сети изб-читален, которые задумывались как центры политико-просветительной работы региона. Однако их практическая деятельность столкнулась с рядом проблем: недостаток материальных ресурсов и инвентаря, низкая квалификация работников. Кроме того, сложность представляло настороженное, и даже враждебное, отношение местного населения к избам-читальням. Автором изучены мероприятия

Антонина Иннокентьевна Мороз - к. и.н., доцент, кафедра Гражданского и уголовного права и процесса, Читинский институт (филиал) ФГБОУ ВО «Байкальский государственный университет», Чита, Россия. Электронная почта: antonina_sazhina@mail.ru 
советской власти, местных ячеек коммунистической партии и комсомола, членов профессиональных союзов, направленные на укрепление забайкальских изб-читален и способы привлечения населения к их работе.

Ключевые слова: просвещение, Восточное Забайкалье, социальная политика, избы-читальни

DOI: $10.17323 / 727-0634-2020-18-1-21-36$

Советская социальная политика первого послереволюционного десятилетия была направлена на удовлетворение общественного запроса на изменения в области образования, здравоохранения, сферы призрения. Планируемые результаты определялись в соответствии с идеологией коммунистической партии (Цыкунов 2006: 67), что проявилось в реформах народного образования. Решая гуманистическую по своему характеру задачу преодоления неграмотности и поднятия общекультурного уровня населения, большевики стремились к формированию условий для воспитания «нового человека», создания «нового общества». Однако в условиях Гражданской войны не менее важным было обеспечение лояльности взрослого трудоспособного населения к мероприятиям советской власти. Достижению этой цели служили специальные учреждения для взрослых- школы, клубы, избы-читальни и т.д. Во второй программе РКП (б), принятой на VIII съезде партии в марте 1919 г., отмечалось, что их деятельность должна способствовать организации «самой широкой пропаганды коммунистических идей» (Восьмой съезд РКП(б) 1959:381).

В статье рассматривается, как эта задача реализовывалась посредством деятельности изб-читален в Восточном Забайкалье. Основное внимание исследователи (Ремизова 1962; Ким 1955; Фрид 1941) обращали на успехи мероприятий государственных и партийных органов по повышению образовательного и культурного уровня трудящихся. И большинство работ отличает всесоюзный уровень анализа, но в последние десятилетия наметилась тенденция изучения региональных условий создания и деятельности изб-читален (Спешилова 2018; Номогоева 2015; Николашин, Кулачков 2014; Ураева 2011; Шаламов 2009). Следует отметить, что среди публикаций по теме имеются работы, выполненные на материале Восточного Забайкалья (Пряженникова 2011). Но тематика не исчерпала себя, а позволяет изучать направления образовательной и просветительной политики советской власти по отношению к взрослому населению в контексте событий Гражданской войны, существования Дальневосточной республики (1920-1922 гг.) и сравнительно поздней советизации региона. Все это определило не только политические и экономические сложности организации изб-читален в забайкальской деревне, но и привело к формированию трудностей, связанных с их популяризацией и вовлечением в работу местного населения.

Для решения исследовательской задачи привлечены ранее неопубликованные источники из фондов Государственного архива Забайкальского 
края и Государственного архива Хабаровского края. Основной массив обнаруженных источников составляют делопроизводственные документы, в которых отражена деятельность руководящих органов и находящихся в их ведении сельских просветительных учреждений. Особый интерес представляют отчеты об обследованиях работы забайкальских изб-читален 1923-1929-го гг. Кроме того, произведён отбор опубликованных источников, в основном - материалов газет и журналов, издававшихся в регионе.

\section{Сельские просветительные учреждения Восточного Забайкалья в условиях Гражданской войны и Дальневосточной республики}

Появление изб-читален в российской деревне относится ко времени Первой мировой войны. По определению Е.Н. Медынского, такие учреждения являлись «суррогатом сельской библиотеки», а их появление вызвано стремлением крестьян к получению информации о событиях на фронте. Организация избы-читальни происходила путём объединения крестьян, в складчину нанимавших дом для устройства коллективных чтений выписываемых газет (Медынский 1923:20). В их стенах также устраивались информационные чтения с целью распространения исторических, агрономических, медицинских знаний (Севостьянова 2013: 398). Такие учреждения сохранялись и поддерживались и в годы революций 1917 г. и во время Гражданской войны, что свидетельствует о высокой заинтересованности в них сельского населения. Поэтому решениями Народного комиссариата по просвещению РСФСР изба-читальня определялась как основная просветительная ячейка в деревне, вокруг объединялись все формы просветительных учреждений (школа для взрослых, библиотека, музей, театр), она становилась местом для проведения массовых мероприятий (чтений, лекций, докладов, выставок, спектаклей).

Открытие изб-читален и привлечение в них взрослых посетителей было важным условием реализации политики советской власти в отношении крестьянства. Необходимо было информировать население о проводимых в стране мероприятиях и их значении, втягивать массы в работу советских учреждений, кооперации, по ликвидации неграмотности и малограмотности, «раскрепощению» женщин, формированию «нового быта». Государство поддерживало сельские просветительные учреждения (средствами, литературой, оборудованием) и стремилось к формированию их яркого и привлекательного образа. В 1919-1920-х гг. архитекторами Высших художественно-технических мастерских создан проект избы-читальни, которая должна была стать центром нового советского села (Хан-Магомедов 2001: 405), а в мае 1922 г. «Правда» опубликовала циркуляр ЦК РКП(б), в соответствии с которым началась кампания «пропаганды изб-читален» (Крупская 2014: 119). 
Значимость и важность работы, проводимой сельскими просветительными учреждениями, предполагали жесткую регламентацию их деятельности. Под руководством Главного политико-просветительного управления РСФСР в 1923 г. было разработано «Положение о избе-читальне», которое установило порядок организации таких учреждений и определило основные направления их работы. В последующие годы были изданы положения и инструкции, упорядочивающие деятельность изб-читален по ликвидации неграмотности, политическому, сельскохозяйственному (агрономическому), кооперативному и санитарному просвещению (Сборник официальных положений и распоряжений 1925).

Создание изб-читален в забайкальской деревне началось позднее, чем в центральных районах страны из-за сложной политической и международной обстановки. Советская власть в регионе была провозглашена в феврале 1918 г., однако просуществовала всего несколько месяцев. Созданный в этот период Забайкальский Областной Комитет по народному образованию объявил о начале реформы народного образования и просвещения на основе декретов и постановлений Народного комиссариата по просвещению РСФСР (Забайкальский рабочий 1918), но воплотить эти планы не удалось. В августе того же года, когда областной центр Чита был занят войсками чехословацкого корпуса и Временного Сибирского правительства, в регионе была установлена белая государственность, ситуация осложнилась интервенцией со стороны Японии и США. В связи с этим вопросы народного образования и просвещения естественным образом отошли на второй план. Только после освобождения и объединения территории Дальнего Востока и Забайкалья в границах Дальневосточной республики в октябре 1920 г. сложились сравнительно благоприятные условия для начала школьной реформы.

Правительство Дальневосточной республики провозгласило необходимость предоставить всем гражданам «всестороннее образование». Решение задачи передавалось в ведение Министерства народного просвещения, которое составило программу мероприятий по созданию единой, демократической, бесплатной и светской школы, в том числе специальных учреждений для обслуживания взрослых (Библиотека ЗККМ им. А.К. Кузнецова. Ед. хр. 843). Для ее реализации развернута активная организационная работа: критика неграмотности и популяризация чтения газет, посещения просветительных мероприятий, издано воззвание о проявлении местной инициативы в открытии образовательных и просветительных учреждений, мобилизовано для работы в них учительство. С целью привлечения внимания к проблемам образования и просвещения взрослых также проведено несколько агитационных кампаний, таких как «День просвещения», «День библиотеки» и «Месяцы ликвидации неграмотности» (Мороз 2017).

Граждане Дальневосточной республики охотно откликались на эти призывы. Создание разнообразных «культурных очагов» ознаменовало переход к мирной жизни. Определённый энтузиазм населения задавала также 
специфика общественно-политической обстановки в стране. В преддверии выборов в Учредительное собрание развернули избирательные кампании политические партии (большевики, менышевики, эсеры, энесы, кадеты), вели агитацию, распространяя собственные газеты и листовки. Стремление взрослых рабочих и крестьян получить информацию о происходящих вокруг них событиях и определить своё отношение к ним, приводило к массовому созданию на местах библиотек, народных домов, клубов, культурнопросветительных кружков (Министерство Народного Просвещения ДВР 1921:21). Информации о практической деятельности таких учреждений крайне мало. Основным её источником являются эпизодические упоминания в документации Министерства народного просвещения и Забайкальского губернского комитета РКП (б), а также небольшие заметки в периодической печати. Известно, что большинство из них возникали стихийно, действовали без каких-либо планов и программ, а содержание их работы находилось в прямой зависимости от интересов обслуживаемого населения.

Высокая степень автономности забайкальских просветительных учреждений вызывала критику со стороны местных коммунистов. Так, на Государственной конференции по народному образованию в мае 1922 г. председатель Забайкальского областного управления Н.Е. Широких требовал подвести материальную базу под деятельность учреждений для взрослых и поставить под контроль властных органов их работу (Министерство народного просвещения ДВР 1922:5-6). Благоприятные условия для этого сложились после ликвидации Дальневосточной республики, присоединения её территории к РСФСР, в условиях однопартийной политической системы и советского государственного строительства.

\section{Избы-читальни в условиях советизации Восточного Забайкалья}

После восстановления советской власти в Восточном Забайкалье в ноябре 1922 г. начались качественные изменения в положении и деятельности образовательных и просветительных учреждений для взрослых. Все мероприятия в области народного образования и просвещения проводились по примеру центральных регионов. Так, был образован Забайкальский губернский отдел народного образования, в составе которого выделен подотдел политико-просветительной работы. В его ведение была передана работа со взрослым населением по ликвидации неграмотности, созданию единой сети просветительных учреждений (изб-читален, клубов, народных домов), а также их методическое и кадровое обеспечение (ГАЗК. Ф. П-81. Оп. 1. Д. 509. Л. 17).

Условия, в которых начало работу Забайкальское губернское политико-просветительное управление, были сложными. Затянувшиеся военные действия подорвали экономический потенциал региона, резко сократилась 
численность местного учительства, были разрушены или захвачены разными ведомствами помещения образовательных и просветительных учреждений. Трудности создавала и специфика забайкальской деревниработу предстояло вести в том числе среди казаков, часть из которых не восприняла установления советской власти и была оппозиционно настроена к ее мероприятиям. Особого подхода требовали проживающие в регионе отдельные этнические и религиозные группы- буряты, тунгусы-орочоны, старообрядцы. Основное внимание Забайкальского губернского политико-просветительного управления было обращено на вовлечение в работу местного крестьянства и казачества, как наиболее крупных и значимых социальных групп региона. Для этого в зимние месяцы 1922-1923 гг. организована кампания по созданию изб-читален, в которой приняли участие члены РКП (б) и комсомола. Однако её практические результаты оказались незначительными. Так, по данным отчётов инструкторов агитационно-пропагандистского отдела Забайкальского партийного комитета, посещаемость создаваемых просветительных учреждений была очень низкой, на неё оказывало свое влияние «смутное» представление местного населения о советской власти и ее мероприятиях и распространенное в его среде опасение «попасть в коммунию» (лишиться личного имущества) (ГАЗК. Там же. Д. 701. Л. 95).

Ярким примером такого отношения является заметка в газете «Забайкальский крестьянин» о событиях в селе Застепь, где была организована одна из первых забайкальских изб-читален. Заведующий, комсомолец Василий Конюков писал:

31 декабря 1922 г. ... часов в 10 утра я прибил на воротах ограды у члена селькома на видном месте афишу о том, что в Застепи открыта изба-читальня и вечером состоится празднование этого события: устраивается «Застепинская Живая газета». Часа через два после этого афишу заплевали и захаркали так, что невозможно было прочесть. Ещё задолго до этого все спрашивали тех членов кружка, кто подписали протокол об открытии избы-читальни: «Ты што, тоже записался в коммуну?». А участников живой газеты разносили кто как мог, в глаза и по заглаза. Посмотреть и послушать пришла только молодёжь да члены культпросвета (Забайкальский крестьянин 1923b).

В условиях советизации подобные события случались массово. Необходимость отчитаться в выполнении поставленной задачи приводила к тому, что организаторы изб-читален прибегали к крайним мерам-нажиму, резкой критике «темноты» и «отсталости» местного населения, разгонам вечорок и посиделок (Просвещение на Дальнем Востоке 1924). Подобные меры не могли исправить ситуацию и привели к началу открытых конфликтов между комсомольцами и местной «неорганизованной» молодёжью. Так, в селе Кирга пьяные хулиганы запугали активистов, которые вели работу по подготовке спектакля, в селе Онохово исключённая из комсомола моло- 
дёжь срывала репетиции театрального кружка, а в поселке Дарасун был сорван и сам спектакль (Забайкальский крестьянин 1923 с).

Потребовалась разъяснительная работа среди населения. Она началась в рамках «культурного шефства» города над деревней, которое развернулось в Забайкальской губернии весной 1923 г. Шефские комиссии, состоящие из представителей городских партийных и комсомольских ячеек, профессиональных организаций и отдельных предприятий, выезжали в сельскую местность, где организовывали избы-читальни, снабжали их литературой, газетами и журналами, а также устраивали различные просветительные мероприятия. Как отмечалось в одном из отчётов Дальневосточной партийной организации, в целом это позволило достигнуть «культурной смычки города с деревней» (ГАЗК. Там же. Л. 289).

Благодаря этому на территории Забайкальской губернии к лету 1923 г. создана сеть изб-читален, состоящая из 98 учреждений (ГАХК. Ф. Р-18. Оп. 5. Д. 3. Л. 30 об.- 31). Однако бюджетных средств на содержание открывшихся учреждений выделено не было и положение их было очень тяжелым: не хватало оборудования, инвентаря, методических руководств. Большую проблему составляло отсутствие подготовленных кадров, способных вести просветительную работу после отъезда шефов. В связи с этим во многих избах-читальнях получили распространение платные спектакли, организуемые силами местной молодёжи. Свидетельства о них в большом количестве содержит местная периодическая печать. Как правило, они отличались слабым уровнем подготовки, низким качеством исполнения, а их тематика определялась личными интересами и симпатиями организаторов (Севостьянова 2012:385). Несмотря на то что такие мероприятия привлекали внимание местного населения, далеко не всегда они получали его поддержку и одобрение. Так, один из посетителей спектакля на станции Оловянная отмечал: «Спектакли, как блины, а культурность не продвигается. К спектаклям не готовятся. Со сцены высмеивают непартийных. Идет война. Это надо прекратить. На войне далеко не уедешь» (Забайкальский крестьянин 1923 а). В результате местное возрастное население тяготело к собственным просветительным учреждениям, созданным в предыдущие годы, а основная масса молодёжи проводила свободное время традиционными способами-на вечорках и посиделках, за карточной игрой или в кулачных боях.

Ситуация в забайкальской деревне обсуждалась в августе 1923 г. на совещании секретарей губернских комитетов РКП(б) и исполнительных комитетов Дальневосточной области. В директивных указаниях, составленных по результатам совещания, отмечалось «захлёстывание мелкобуржуазной мещанской стихией» просветительной работы в деревне, ставились задачи «вышибить почву из-под ног деревенских театралов» и перевести работу со взрослыми на «здоровые политические и производственные рельсы» (ГАХК. Там же. Л. 18 об.). В сентябре на места выслано циркуляр- 
ное письмо с требованием реорганизации сети сельских просветительных учреждений. В соответствии с ним, началось формирование так называемых «советов изб-читален», в которые входили представители местных ячеек РКП(б) и комсомола, женотдела, профессиональных союзов, учительства, а все самостоятельные просветительные учреждения объединялись вокруг них (ГАХК. Там же. Л. 19 об.-20).

Сложившаяся в этих условиях сеть изб-читален Забайкальской губернии, к осени 1923 г. включала в себя 89 учреждений, в том числе- 41 бюджетное и 48 внебюджетных (ГАЗК. Там же. Д. 1159. Л. 102). Первые существовали за счет выделения средств из губернского бюджета, вторые- на средства, получаемые от партийных, комсомольских и профессиональных организаций и местного населения. При этом и те и другие выстраивали свою деятельность по планам Забайкальского губернского политико-просветительного управления и были полностью подконтрольны ему.

\section{«План работы избы-читальни»}

Проведенные мероприятия позволили урегулировать ведение политико-просветительной работы в забайкальской деревне, сформировать её основные направления. На первом месте стояло информирование местного населения о целях советской власти, содержании проводимой ею внутренней и внешней политики. Поскольку значительная часть взрослого населения региона в этот период оставалась неграмотной или малограмотной, просветительная работа велась путём лекций и докладов, коллективных чтений советских газет «Правда», «Беднота», «Экономическая жизнь», журналов «Крестьянка» и «Безбожник» (ГАЗК. Там же. Л. 102-103). Такие мероприятия были не только способом распространения информации, но и средством идеологической обработки населения. Углубленную работу в этом направлении также вели создаваемые в каждом учреждении кружки политической грамотности (ГАЗК. Ф. Р-1448. Оп. 1. Д. 161. Л. 14).

Большое внимание в работе изб-читален уделялось сельскохозяйственной пропаганде. Преодоление послевоенной разрухи и восстановление крестьянских хозяйств требовали введения научных знаний и технических новшеств в жизнь деревни. Ознакомление с ними забайкальских крестьян достигалось с помощью разных мероприятий. Так, изучение сценариев «живых журналов» изб-читален Борзинского уезда в 1924-1925 гг. показало, что этим вопросам уделялось внимание в каждом выпуске. Среди содержащихся в них публикаций встречаются доклады, декламации и инсценировки на темы «Производительность труда», «Советское хозяйство», «О тракторе», «Преступное отношение к лошади», «Птица ухода требует», «Бешенство животных» (ГАЗК. Там же. Д. 250. Л. 1-140). Ещё одной формой сельскохозяйственной пропаганды были постановочные суды, в которых в роли обвиняемых оказывались консервативные крестьяне, не желавшие 
повышать свою трудовую культуру. Для тех же, кто проявлял к этим вопросам особый интерес, создавались специальные сельскохозяйственные кружки (ГАЗК. Там же. Д. 161. Л. 14).

Важным направлением работы забайкальских изб-читален было воспитание у местных жителей материалистического мировоззрения в сочетании с антирелигиозной пропагандой (Левченко 2012:363). Понимая, что прямая критика и нажим могут оттолкнуть население, они проводили её с особой осторожностью. Среди основных форм работы преобладали лекции и доклады по естественнонаучным темам. Помимо этого большое внимание уделялось популяризации новых советских праздников, призванных заменить праздники религиозные. Одним из них был День урожая, начало празднования которого в забайкальской деревне относится к 1924 г. В этот день избы-читальни организовали массовые мероприятия. Так, в селах Кубухай и Даурия прошли торжественные митинги, в селах Бада, Карымское и поселке Борзя устроены выставки, а в село Шилка к праздничному дню доставлен трактор, демонстрация которого вызвала огромный интерес у местных жителей (Забайкальский рабочий 1924а). Аналогичную работу избы-читальни вели в отношении социально значимых обрядов. Практика «октябрин», «комсомольских свадеб», «красных похорон» должна была вытеснить церковные крещения, венчания и отпевания. Такие мероприятия были публичными, в обязательном порядке сопровождались лекциями и докладами о политике советской власти в социальной сфере, торжественными концертами или постановкой спектаклей. Отчёты об их проведении часто помещала местная периодическая печать (Забайкальский рабочий $1924 \mathrm{~b}, 1925 \mathrm{a}, \mathrm{c}, \mathrm{e})$.

Значительное внимание забайкальские избы-читальни уделяли работе среди женщин, которую они вели совместно с женотделами. Как правило, эти организации проводили в помещениях сельских просветительных учреждений свои собрания, читали лекции для «неорганизованного» женского населения, устраивали громкие чтения, выставки, оформляли «уголки крестьянки» и «уголки матери и ребенка». В связи с тем, что содержание советской гендерной политики вызвало протест у значительной части жителей забайкальской деревни, а её реализация проходила в обстановке острого социального конфликта, избы-читальни также изыскивали благовидные предлоги для привлечения женского населения к своей работе. Так, во многих учреждениях создавались домоводческие кружки, в которых девушки и женщины могли получить навыки приготовления пищи, рукоделия (шитья, вязания, прядения) и ознакомиться с правилами и нормами ведения домашнего хозяйства (ГАЗК. Там же. Д. 235. Л. 28-28 об.). Кроме того, все сельские просветительные учреждения принимали активное участие в организации Дня работницы и крестьянки. Так, в 1924 г. он был отмечен докладами, торжественными собраниями, спектаклями и специальными выпусками «живых журналов». Интересен 
опыт проведения праздника в селе Куэнга, где в местной избе-читальне состоялся постановочный «Суд над женщиной, не принимающей участия в общественной работе и жизни деревни». По сообщению газеты «Забайкальский крестьянин», участники процесса, приняв во внимание забитость и неразвитость крестьянки, находящейся под властью мужа, оправдали её, но вынесли порицание мужьям, держащим своих жён «в ежовых рукавицах» (Забайкальский крестьянин 1924).

Значимым направлением в деятельности изб-читален была санитарнопросветительная работа. Санитарное состояние условий местной деревенской жизни было плачевным, а военные годы усугубили ситуацию. Сокращение числа медицинских учреждений и медработников стимулировало широкое распространение таких лечебных практик, как знахарство и шаманское лечение. Поэтому избы-читальни уделяли внимание чтению лекций о профилактике наиболее опасных заболеваний, правилах и нормах хранения пищи, важности поддержания чистоты в местах общего водопользования и в жилых помещениях, пропагандировали необходимость своевременного обращения в лечебные учреждения. Кроме того, в летние месяцы 1924 и 1925 гг. они приняли участие в трёхдневниках по борьбе с социальными болезнями (алкоголизмом, проституцией, сифилисом, туберкулезом) и провели выставки, санитарно-просветительные суды, спектакли соответствующей тематики (Забайкальский рабочий $1925 \mathrm{~d}$ ). Особенное значение это имело в Петровско-Заводском уезде, среди населения которого значительной была доля бурят и старообрядцев, не признающих официальной медицины.

Забайкальские избы-читальни вели работу по «оздоровлению» досуга взрослого населения: осуждали гулянки, вечорки и посиделки и популяризировали так называемые «разумные развлечения» (посещение культурных мероприятий, чтение газет и журналов, настольные игры, кино).

\section{Проблемы изб-читален Восточного Забайкалья и их решения}

Реализация основных направлений практической работы забайкальских изб-читален встретила препятствия, главным из которых была слабая материальная база. Выделенные из губернского бюджета средства позволяли покрыть лишь отопление и освещение помещений, оплату труда избача. Проблемой была и недостаточная подготовка занятых кадров. Чаще всего должности избачей замещались молодыми комсомольцами или школьными учителями, не имеющими опыта ведения политико-просветительной работы. В результате сильно страдало её качество, снижалась посещаемость изб-читален.

Для изменения ситуации были увеличены средства, выделяемые на нужды изб-читален, созданы так называемые показательные или «опорные» учреждения, а также организованы ежегодные курсы для избачей. 
Кроме того, в январе 1925 г. на территории Забайкальской губернии проведена агитационная кампания «Помощи избе-читальне», в которой приняли участие государственные, партийные, комсомольские, профессиональные организации и местная периодическая печать (ГАХК. Ф. Р-58. Оп. 1. Д. 85. Л. 62 «а» об.). В Чите на базе губернской центральной библиотеки был организован сбор литературы, а служащие финансового управления Борзинского уезда произвели отчисление части заработной платы на покупку газет и журналов для местных учреждений. Интересен также опыт участия в кампании редакции газеты «Забайкальский крестьянин», коллектив которой создал передвижной «живой журнал» для обслуживания сёл, расположенных в окрестностях Читы (Забайкальский рабочий 1925b).

Помимо агитационной работы понадобились изменения в деятельности изб-читален. Довольно скоро у местного руководства сформировалось понимание того, что у взрослого крестьянства наибольший интерес вызывали мероприятия, из которых можно было извлечь конкретную пользу. Популярностью пользовались справочные столы и юридические консультации. Так, в 1926 г. за четыре месяца справочной работы избами-читальнями Читинского и Сретенского округов выдано 722 справки по судебным, земельным и налоговым вопросам (ГАЗК. Ф. П-75. Оп. 1. Д. 495. Л. 16 об.).

Немаловажную проблему представляла организация политико-просветительной работы среди полуоседлого и кочующего населения региона. По данным Забайкальского губернского политико-просветительного управления эта работа велась эпизодически в связи с отсутствием кадров (ГАЗК. Ф. П-81. Оп. 1. Д. 701. Л. 193). Иллюстрацией служит составленное в марте 1926 г. председателем сельсовета Новая Заря Дылгыровым Цыгдыном обращение в местный партийный комитет, где отмечено:

Мы буряты в числе 420 хозяйств проживаем в пределах ДВК в Борзинском районе. Мы оторванные от сородичей Бурреспублики и бурят других [неразборчиво], отсутствием развитых сограждан среди нас никакая политпросветительная организационно-политическая работа не ведется, ибо нет сил (ГАЗК. Там же. Д. 1261. Л. 126-126 об.).

В этих условиях необходимо было искать особые формы взаимодействия (Карпов 1997: 104). Таковыми стали организованные в 1926 г. передвижные библиотеки и школы грамотности для бурят на территории Хаоцайского и Хилоко-Бурятского районов Читинского округа (ГАЗК. Ф. П-75. Оп. 1. Д.213. Л. 50 об.). Кроме того, разработан проект училищно-медико-кооперативной школы-интерната для обслуживания орочонского населения, в структуре которой предусмотрены общежитие для детей, заезжий дом для родителей, фельдшерский пункт, склады для хранения огнеприпасов и мехов, торговая лавка, а также небольшие кузнечные, столярные и бондарные мастерские. Одна из таких школ открыта в 1926 г. в селе Талача Олинского района Сретенского округа (ГАЗК. Ф. П-71. Оп. 1. Д. 530. Л. 104). 
В целом, проводимые мероприятия способствовали расширению охвата политико-просветительной работой населения забайкальской деревни. В 1926 г. на заседании агитационной коллегии Дальневосточного краевого комитета ВКП(б) отмечалось, что «политико-просветительная работа в Дальневосточном крае период организационного оформления прошла. Изба-читальня как иентр всей политико-просветительной работы в деревне вылявлена» (ГАЗК. Ф. П-75. Оп. 1. Д. 203. Л. 11). Об этом также свидетельствуют данные о соотношении числа бюджетных и внебюджетных учреждений. Сеть изб-читален одного только Читинского округа в $1926-$ 1927 гг. включала в себя 31 бюджетное и 172 внебюджетных учреждения (ГАЗК. Там же. Д. 213. Л. 44 об.; Д. 717. Л. 50). То обстоятельство, что население охотно открывало избы-читальни и принимало на себя обязанности по их содержанию, говорит о том, что они завоевали внимание деревни.

\section{Заключение}

Изба-читальня, как центр просвещения деревенского населения, начала становление еще в дореволюционный период, хотя массовый характер деятельность таких учреждений приобрела благодаря целенаправленной политике советской власти. Большевики придавали работе изб-читален большое значение и наполнили её новым содержанием. Явные функции этих учреждений (образовательная, просветительная, коммуникативная, досуговая) были дополнены латентной функцией идеологического воспитания взрослого населения на основе установок коммунистической партии и советских ценностей. В научной литературе влияние этого обстоятельства на практическую деятельность изб-читален изучено недостаточно.

В рамках данного исследования на материалах Восточного Забайкалья удалось установить, что политическая направленность деятельности изб-читален зачастую отталкивала консервативное взрослое население. Первые мероприятия по созданию и популяризации деятельности таких учреждений в забайкальской деревне привели к социальным конфликтам. Местное население отказывалось посещать избы-читальни и предпочитало им самодеятельные просветительные учреждения, а также традиционные формы проведения досуга. Изменение ситуации потребовало введения прямого запрета на ведение иной просветительной работы в деревне. Использование административного ресурса способствовало повышению посещаемости изб-читален. Вместе с тем завоевание авторитета не могло обойтись без ориентации практической деятельности изб-читален на потребности местного населения. Политическое просвещение велось наравне с разнообразной работой по улучшению крестьянского труда и быта. Сочетание этих мер уже к концу 1920-х гг. способствовало превращению изб-читален в центры социокультурной жизни забайкальской деревни. 


\section{Список сокращений}

ГАЗК- Государственный архив Забайкальского края.

ГАХК - Государственный архив Хабаровского края.

ЗККМ- Забайкальский краевой краеведческий музей им. А. К. Кузнецова

\section{Список неопубликованных и опубликованных материалов}

Библиотека ЗККМ им. А.К. Кузнецова. Ед. хр. 843.

ГАЗК. Ф. П-71. ОП. 1.

ГАЗК. Ф. П-75. ОП. 1.

ГАЗК. Ф. П-81. ОП. 1.

ГАЗК. Ф. Р-1448. ОП. 1.

ГАХК. Ф. Р-18. ОП. 5.

ГАХК. Ф. Р-58. Оп. 1.

Забайкальский крестьянин (1923 а) Наши сельские школы, 11 февраля: 2 .

Забайкальский крестьянин (1923b) Свет и тьма, 4 марта: 3.

Забайкальский крестьянин (1923 с) Хулиганы, срывающие работу, 10 мая: 2 .

Забайкальский крестьянин (1924) Культурная работа в деревне, 27 апреля: 6.

Забайкальский рабочий (1918) Резолюция секции по народному образованию III областного съезда сельского населения, 14 апреля: 2-3.

Забайкальский рабочий (1924а) Красный праздник в деревне, 25 ноября: 4.

Забайкальский рабочий (1924b) Новый быт в деревне, 24 июля: 7.

Забайкальский рабочий (1925а) Деревня в новом быту, 26 марта: 6.

Забайкальский рабочий (1925b) Живая газета в деревне, 8 января: 6.

Забайкальский рабочий (1925 с) Зернышки нового быта деревни, 6 августа: 6 .

Забайкальский рабочий (1925d) На санитарно-просветительной выставке, 1 августа: 6.

Забайкальский рабочий (1925е) Новый быт, 1 марта: 6.

Министерство Народного Просвещения ДВР (1921) Реформа. Чита: Электротипография ДВСПС.

Министерство народного просвещения ДВР (1922) К Государственной конференции по народному образованию. Бюллетень Министерства народного просвещения ДВР, 10 июня: 5-6.

Просвещение на Дальнем Востоке (1924) Изба-читальня и деревенские посиделки, 11 ноября: 2-3.

Сборник официальных положений и распоряжений (1925) Изба-читальня как центр политико-просветительной работы в деревне. Верхнеудинск: Гостипография Буркомпромторга. 


\section{Список источников}

Восьмой съезд РКП (б) (1959) Mapm 1919 г. Протоколь. М.: Государственное изд-во политической литературы.

Карпов Е.В. (1997) Из опыта социально-экономических преобразований жизни малых народов Севера Забайкалья. Историко-экономические исследования, (2): 98-107.

Ким М.П. (1955) Коммунистическая партия-организатор культурной революции в СССР. М.: Госполитиздат.

Крупская Н.К. (2014) Основные типы политпросветучреждений. Основы политикопросветительной работы. М: Директ-Медиа.

Левченко И.В. (2012) Религия в развитии российского государства: история и современность. В.М. Левченко (ред.). Иркутский историко-экономический ежегодник. Иркутск: Издво БГУЭП:361-366.

Медынский Е.Н. (1923) Энциклопедия внешкольного образования: лекции, читанные на педагогическом факультете Уральского университета в 1920-1922, 1-2 (2). М-Пг.: [Б. и.].

Мороз А.И. (2017) Деятельность Внешкольного отдела Министерства народного просвещения ДВР (1920-1922 гг.). Гуманитарный вектор, 12 (4): 47-54.

Николашин В.П., Кулачков В. В. (2014) Избы-читальни российской провинции 1920-х гг. как трансляторы советских ценностей. Былые годы, 34 (4): 651-654.

Номогоева В.В. (2015) Изба-читальня в первые годы советской власти (на примере Бурятии). Вестник Бурятского государственного университета, (7): 76-81.

Пряженникова М.В. (2011) Организация и деятельность избы-читальни в Забайкалье в 1920-е годы. Л.Б. Жабаева (ред.). Народы Сибири в составе Российского государства: история и современность. Улан-Удэ: Изд-во ВСГТУ:232-238.

Ремизова Т. А. (1962) Культурно-просветительная работа в РСФСР. М.: Наука.

Севостьянова Е.В. (2012) Любительские спектакли в сельских поселениях Восточной Сибири в конце XIX- начале XX века. В. М. Левченко (ред.) Иркутский историкоэкономический ежегодник. Иркутск: Изд-во БГУЭП: 382-387.

Севостьянова Е. В. (2013) Народные чтения в досуговой сфере сельского населения Восточной Сибири в конце XIX- начале XX века. В. М. Левченко (ред.) Иркутский историко-экономический ежегодник. Иркутск: Изд-во БГУЭП: 392-402.

Спешилова Е. В. (2018) Деятельность сельских культурно-просветительных учреждений Приморья в 1923-1925 гг. Гуманитарные исследования в Восточной Сибири и на Дальнем Востоке, (1): 73-77.

Ураева И.В. (2011) Развитие библиотечной сети в Тамбовском регионе в 1917-1941 гг. Социально-экономические явления и прочессы, 3-4 (25-26): 401-406.

Фрид Л. С. (1941) Очерки по истории развития политико-просветительной работы в РСФСР (1917-1929 г2.). Л.: Наука.

Хан-Магомедов С.О. (2001) Архитектура советского авангарда. В 2 кн. Кн.2: Социальные проблемы. М.: Стройиздат.

Цыкунов Г.А. (2006) Реформы в российской истории. В. М. Левченко (гл. ред.). Иркутский историко-экономический ежегодник. Иркутск: Изд-во БГУЭП: 64-70.

Шаламов В. А. (2009) Изба-читальня как форма повседневного досуга сельских жителей Ангаро-Енисейского региона в 20-30 гг. XX века. М.П. Демина (ред.) Интеллектуальные и материальные ресурсы Сибири. Иркутск: Изд-во БГУЭП: 38-44. 
Antonina Moroz

\section{THE VILLAGE READING ROOMS OF THE EASTERN TRANS-BAIKAL REGION IN THE 1920s}

The article examines the creation and operation of Soviet political and educational institutions for the adult peasantry, the so-called izba-chital'nia (village reading rooms) of the Eastern Trans-Baikal region. The article is based on historical documents not previously studied from the State Archives of the Trans-Baikal region and the Khabarovsk region, as well as periodicals from the 1920s. The creation of a network of izba-chital'nia in the region occurred later than in central Russia. In 1920-1922, organisations of different kinds (libraries, community halls, etc.) were established. However, the studied sources contain no reference to rural library huts. The establishment of this new type of organisation was the result of decentralizing public education management in the republic, as well as the involvement of the regional population in creating educational institutions from below. This made TransBaikalian educational institutions for adults independent; they could operate without subordination to central plans, instructions, and restrictions. After the establishment of Soviet power, a network of izba-chital'nia was established to act as centers of political and educational work among the inhabitants of the region. Their operation faced a number of problems such as a lack of resources, the low qualification of employees, as well as the cautious or even hostile attitude of the local population. The actions of the Soviet government, the local cells of the Communist Party and the Komsomol, and members of trade unions, all sought to strengthen the Trans-Baikal izba-chital'nia and find new ways to include the population in their work.

Key words: education, Eastern Trans-Baikal, social policy, izba-chital'nia

DOI: 10.17323/727-0634-2020-18-1-21-36

\section{References}

Frid L. S. (1941) Ocherki po istorii razvitiya politiko-prosvetitel'noy raboty v RSFSR (1917$1929 \mathrm{gg}$.) [Essays on the History of the Development of Political and Educational Work in the RSFSR (1917-1929)]. Leningrad: Nauka.

Karpov E. V. (1997) Iz opyta social'no-ekonomicheskih preobrazovanij zhizni malyh narodov Severa Zabajkal'ya [From the Experience of Social and Economic Transformations in the Life of the Small Nations of Transbaikalian North]. Istoriko-ekonomicheskie issledovaniya [Historical and Economical Investigations], (2): 98-107.

Khan-Magomedov S.O. (2001) Arkhitektura sovetskogo avangarda. In 2 Vol. Vol. 2: Sotsial'nye problemy [Soviet Avant-garde Architecture. Social Problems]. Moscow: Stroyizdat.

Kim M.P. (1955) Kommunisticheskaya partiya-organizator kul'turnoy revolyutsii v SSSR [The Communist Party- The Organizer of the Cultural Revolution in the USSR]. Moscow: Gospolitizdat.

Antonina I. Moroz- PhD in History, Associate Professor, Department of Civil and Criminal Law and Process, Chita Institute (branch) of Baikal State University. Chita, Russian Federation. Email: antonina_sazhina@mail.ru 
Krupskaya N.K. (2014) Osnovy politiko-prosvetitel'noy raboty [General Types of Political Educational Institutions. The Basics of Political and Educational Work]. Moscow: Direkt-Media.

Levchenko I. V. (2012) Religiya v razvitii rossijskogo gosudarstva: istoriya i sovremennost' [Religion in the Development of the Russian State: History and our Time]. In: V. M. Levchenko (ed.). Irkutskij istoriko-ekonomicheskij ezhegodnik [Irkutsk Historical and Economic Yearbook]. Irkutsk: Izd-vo BGUEP:361-366.

Medynskiy E. N. (1923) Entsiklopediya vneshkol'nogo obrazovaniya: lektsii, chitannye na pedagogicheskom fakul'tete Ural'skogo universiteta v 1920-1922, 1-2 (2) [The Encyclopedia of Outof-school Education: Lectures Delivered at the Pedagogical Faculty of Ural University in 19201922]. Moscow-Petrograd: [B. i.].

Moroz A. I. (2017) Deyatel'nost' Vneshkol'nogo otdela Ministerstva narodnogo prosveshcheniya DVR (1920-1922 gg.) [The Activities of the Out-of-school Department of the Ministry of Education in the Far-Eastern Republic (1920-1922)]. Gumanitarnyj vector [Humanitarian Vector], 12 (4): 47-54.

Nikolashin V.P., Kulachkov V.V. (2014) Izby-chital'ni rossiyskoy provintsii 1920-kh gg. kak translyatory sovetskikh tsennostey [The Village Reading Rooms of Russian Province of 1920s as Translators of Soviet Values]. Bylye gody [The Last Years], 34 (4): 651-654.

Nomogoeva V.V. (2015) Izba-chital'nya v pervye gody sovetskoy vlasti (na primere Buryatii) [Village Reading Rooms in the First Years of Soviet Power (the Case of Buryatia)]. Vestnik Buryatskogo gosudarstvennogo universiteta [Bulletin of the Buryat State University], (7):76-81.

Pryazhennikova M.V. (2011) Organizatsiya i deyatel'nost' izby-chital'ni v Zabaykal'e v 1920-e gody [The Organization and Activity of Reading Rooms in Transbaikalia in the 1920s.]. In: L.E. Zhabayeva (ed.) Narody Sibiri v sostave Rossiyskogo gosudarstva: istoriya i sovremennost' [The Peoples of Siberia as Part of the Russian State: History and Modernity]. Ulan-Ude: Izd-vo VSGTU:232-238.

Remizova T.A. (1962) Kul'turno-prosvetitel'naya rabota v RSFSR [Cultural and Educational Work in the RSFSR]. Moscow: Nauka.

Sevostyanova E. V. (2012) Lyubitel'skie spektakli v sel'skih poseleniyah Vostochnoj Sibiri v konce $X I X$-nachale HKH veka [Amateur Performances in the Rural Settlements of Eastern Siberia in the Late $19^{\text {th }}$ and Early $20^{\text {th }}$ Century]. In: V.M. Levchenko (ed.) Irkutskij istoriko-ekonomicheskij ezhegodnik [Irkutsk Historical and Economic Yearbook]. Irkutsk: Izd-vo BGUEP:382-387.

Sevostyanova E. V. (2013) Narodnye chteniya $v$ dosugovoj sfere sel'skogo naseleniya Vostochnoj Sibiri v konce XIX-nachale HKH veka [Public Readings in the Leisure Sector of Rural Population of Eastern Siberia in the Late $19^{\text {th }}$ and Early $20^{\text {th }}$ Century]. In: V. M. Levchenko (ed.) Irkutskij istoriko-ekonomicheskij ezhegodnik [Irkutsk Historical and Economic Yearbook]. Irkutsk: Izd-vo BGUEP:392-402.

Shalamov V. A. (2009) Izba-chital'nya kak forma povsednevnogo dosuga sel'skih zhitelej AngaroEnisejskogo regiona v 20-30 gg. XX veka. [The Village Reading Room as a Form of Daily Leisure of Rural Residents of the Angara-Yenisei region in the 1920s and 1930s]. In: M.P. Demina (ed.) Intellektual'nye i material'nye resursy Sibiri [The Intellectual and Material Resources of Siberia]. Irkutsk: Izd-vo BGUEP:38-44.

Speshilova E. V. (2018) Deyatel'nost' sel'skih kul'turno-prosvetitel'nyh uchrezhdenij Primor'ya v 1923-1925 gg. [The Activities of Rural Cultural and the Educational Foundations of Primorye in 1923-1925]. Gumanitarnye issledovaniya v Vostochnoj Sibiri i na Dal'nem Vostoke [Humanitarian Research in Eastern Siberia and the Far East], (1): 73-77.

Tsykunov G. A. (2006) Reformy v rossijskoj istorii [Reforms in Russian History]. In: V.M. Levchenko (ed.). Irkutskij istoriko-ekonomicheskij ezhegodnik [The Irkutsk Historical and Economic Yearbook]. Irkutsk: Izd-vo BGUEP:64-70.

Uraeva I. V. (2011) Razvitie bibliotechnoy seti v Tambovskom regione v 1917-1941 gg [The Development of a Library Network in Tambov Region: 1917-1941]. Sotsial'no-ekonomicheskie yavleniya i protsessy [Socio-economic Phenomena and Processes], 3-4 (25-26): 401-406.

The Eighth Congress of the VKPB (1959) Mart 1919 g. Protokoly [Proceedings of March 1919]. Moscow: Gosudarstvennoe izd-vo politicheskoy literatury. 